\title{
Performance and meat carcass characteristics of locally slaughtered sheep and goats raised by grazing native tropical grasses with or without supplementation'
}

Abner A. Rodríguez $z^{2 *}$, Elsie E. González $z^{3}$ and Paul F. Randel ${ }^{4}$

J. Agric. Univ. P.R. 98(2):129-146 (2014)

\begin{abstract}
This study was divided into two parts. In the first part, data were collected from $\mathbf{5 7}$ sheep and $\mathbf{2 8}$ goats from different origins and slaughtered in abattoirs in the western region of Puerto Rico to develop a database of the carcass characteristics of small ruminant (SR) raised under traditional feeding management. The second part consisted of a feeding trial in which weaned lambs $(n=6)$ and kids $(n=6)$ were randomly assigned within species to one of two feeding regimes: with or without daily commercial concentrate (CC) supplementation, at the rate of $0.9 \%$ of body weight (BW) on a dry basis, to grazing native tropical grasses. Treatment effects on body weight gain, carcass characteristics, and meat quality were evaluated. The database on carcass characteristics of SR slaughtered commercially showed highly variable dressing percentages ranging from 37 to $46 \%$, and 32 to $38 \%$ for sheep and goat, respectively, both species having similar $(P>0.05)$ average values. No differences were observed in dressing percentages between the sexes. Supplementation with $C C$ increased $(P<0.05)$ total and daily $B W$ gain in lambs by 2,580 and $40 \mathrm{~g}$, respectively, when compared to the non-supplemented controls. In kid-goats, BW gains with supplementation were appreciably, but not significantly greater $(P>0.05)$ than without supplementation. Dressing percentage, and fore and hind trunk percentages did not vary $(P>0.05)$ between treatments for either species. There were no differences $(\mathrm{P}>0.05)$ in $\mathrm{pH}$, moisture, crude protein, and fat percentages of longissimus muscle between treatments in either species. This research revealed the need to develop a local grading system to standardize the meat and improve its quality. Similarly, genetic selection of animals as well as research on alternative less-expensive feed resources for finishing meattype animals are necessary to improve quantity and quality of local small ruminant meat (SRM).
\end{abstract}

Key words: performance, carcass, goats, sheep, supplementation

${ }^{1}$ Manuscript submitted to Editorial Board 28 February 2014.

${ }^{2}$ Professor, Department of Animal Science, University of Puerto Rico, Mayagüez Campus. *Corresponding author

${ }^{3}$ Ex-Graduate Student, Department of Animal Science.

${ }^{4}$ Professor, Department of Animal Science. 


\title{
RESUMEN
}

\begin{abstract}
Características de rendimiento y de la carne de canales de ovinos y caprinos alimentados en pastoreo de gramíneas tropicales nativas con o sin suplementación y sacrificados en mataderos locales
\end{abstract}

Se realizó un estudio dividido en dos partes. En la primera parte, se recolectaron datos de 57 ovinos y 28 caprinos, de diferentes orígenes, sacrificados en mataderos de la región oeste de Puerto Rico para desarrollar una base de datos sobre las características de la canal de pequeños rumiantes (PR) criados bajo el manejo alimentario tradicional. La segunda parte consistió de un ensayo de alimentación en el que corderos $(n=6)$ y cabritos $(n=6)$ se asignaron de forma aleatoria dentro de cada especie a uno de dos regímenes de alimentación: con o sin suplementación diaria con alimento concentrado comercial (CC), a razón de $0.9 \%$ del peso vivo (PV) en base seca, para evaluar el efecto de los tratamientos sobre la ganancia de peso, características de la canal, y calidad de carne bajo pastoreo de gramíneas tropicales nativas. La base de datos de las características de la canal demostró un porcentaje de rendimiento al tamente variado, abarcando de 37 a $46 \%$, y 32 a $38 \%$ para ovinos y caprinos, respectivamente, teniendo ambas especies un valor medio similar $(P>0.05)$. No se observaron diferencias $(P>0.05)$ en el porcentaje de rendimiento entre sexos. La suplementación con $\mathrm{CC}$ aumentó $(\mathrm{P}<0.05)$ por $2,580 \mathrm{~g}$ y $40 \mathrm{~g}$ la ganancia de peso total y diaria, respectivamente, en corderos en comparación con los no suplementados. En los cabritos las ganancias de peso con suplementación fueron apreciables pero no significativamente mayores $(\mathrm{P}>$ $0.05)$ que en aquellos no suplementados. El porcentaje de rendimiento y los porcentajes de cuartos delantero y trasero no variaron $(P>0.05)$ entre los tratamientos en ninguna de las especies. Tampoco hubo diferencias $(P>0.05)$ en $\mathrm{pH}$ ni en los porcentajes de humedad, proteína bruta y grasa en el músculo longissimus dorsi entre tratamientos en ninguna de las especies. Esta investigación reveló que es preciso desarrollar un sistema de clasificación local para estandarizar la carne de pequeños rumiantes (CPR) y mejorar su calidad. También es necesaria la selección genética de los animales, así como la investigación sobre fuentes alimentarias alternas menos costosas para la fase de terminación de animales tipo carne para mejorar la cantidad y calidad de la CPR local.

Palabras clave: rendimiento, canales, ovinos, caprinos, suplementación

\section{INTRODUCTION}

In Puerto Rico, sheep and goats are raised mainly for meat production under extensive conditions grazing naturalized tropical grasses (NTG) without supplementation. During the last decade a decrease in local small ruminant meat (SRM) production has occurred and this lower production has coincided with a higher demand for sheep (lamb/ mutton) and goat (kid goat/chevon) meat, associated perhaps with an increase in various ethnic populations, as well as the health and gourmet food preferences of certain consumer segments. The unique taste and nutritive characteristics associated with goat and sheep meat foster this trend. The increased local demand is satisfied by a higher rate 
of importation (Department of Agriculture of Puerto Rico, 2008; Foreign Trade Statistics, 2004). One of the problems affecting the small ruminant industry in Puerto Rico is the lack of detailed information on demand, consumer preferences, niche markets, and other aspects of the meat that affect the synchrony between market preferences and product supply. This problem, in addition to the limited information on the nutritive value of SRM, has caused many former producers to shift to other businesses during recent years. Additionally, ruminant production in Puerto Rico is mainly supported by grazing NTG due to their low cost and availability. The poor quality of this type of forage results in low dry matter (DM) intake, animal weight loss during certain periods, increased disease susceptibility, low reproductive performance, and failure to realize animal genetic potential (Murphy et al., 1994). These results explain the low rate of BW gains, and poor carcass conformation and meat quality reported in the literature for ruminants under tropical grazing systems without supplementation (Liméa et al., 2009). The low quality of NTG has forced progressive meat-type animal producers to implement supplementation strategies during the growing and finishing phases; commercial concentrate (CC) being the most commonly used feedstuffs for this purpose in Puerto Rico. However, local CCs are compounded from imported ingredients, which increases feeding costs. Different studies performed in tropical areas have yielded variable results of CC supplementation on SR performance. Some studies have shown important differences in growth rate, carcass characteristics and meat chemical composition between supplemented and non-supplemented animals (Karim et al., 2006; Liméa et al., 2009). Locally, there is little experimental evidence regarding the effect of CC use on the performance of sheep and goats raised while grazing NTG. Another existing problem for the local SR industry is the lack of available information on carcass characteristics and meat quality of animals slaughtered under traditional management, and how supplementation with $\mathrm{CC}$ affects these variables. This research was designed in two parts to develop a data base of the carcass characteristics and meat quality of SR slaughtered after being raised under traditional feeding management in Puerto Rico; and to test the effect of supplementation with a CC on BW gain, carcass characteristics, and meat quality of weaned lambs and kids raised by grazing native tropical grasses.

\section{MATERIALS AND METHODS}

In the first part of the study, to establish the carcass characteristics of SR slaughtered on the island, data were collected from eighty-five 
crossbred animals processed at two abattoirs located in the western region of Puerto Rico (Lajas and Mayagüez), and included 57 sheep (40 females and 17 males) and 28 goats ( 17 females and 11 males) from different origins and raised under grazing conditions without supplementation. All animals evaluated were in the adult stage (determined by number of permanent teeth present) and had an average weight of $28 \mathrm{~kg}$ at slaughter. Live and warm carcass weights were taken to calculate the dressing percentage. A t-test for independent samples was performed for mean comparisons of the dressing percentage between species, and sex within the same species, using $\mathrm{P}=0.05$ significance level.

The second part of the study tested the effect of supplementation with a $\mathrm{CC}$ on $\mathrm{BW}$ gain, carcass characteristics, and meat quality of crossbred-weaned lambs and kid-goats. The experiment was conducted in the Small Ruminant Project at the Alzamora Farm of the University of Puerto Rico, Mayagüez Campus (UPRM). Six intact male crossbred kid-goats $(B W=17.58 \mathrm{~kg})$ and six intact male crossbred lambs $(B W=$ $15.98 \mathrm{~kg}$ ) were used. These animals were obtained from commercial producers, and before weaning had been raised grazing NTG without supplementation. Under conditions of the present experiment kids and lambs also grazed NTG and received grass hay. They were assigned in a completely randomized design to one of two additional feeding regimes: with (CC) or without (NCC) concentrate supplementation. Each treatment was replicated with three animals per species. The CC supplement was offered daily in the morning in individual feeders at the rate of $0.9 \%$ of animal BW on a dry matter basis (DMB) during 62 days. Animals had access to tropical grass pastures, with swards composed mainly of guineagrass (Panicum maximum), for at least six hours of grazing during the day and were confined at night with ad libitum access to grass hay and water. Rotational grazing was implemented among three paddocks $\left(930,1058\right.$, and $\left.1333 \mathrm{~m}^{2}\right)$ in 21-day cycles. Prior to initiation of the feeding trial, animals were weighted, and orally dewormed with a commercial anthelmintic. Body weight was taken at 0 , $7,14,21,28,35,42,49,56$, and 62 days and weight gain was expressed on the total, weekly, and daily basis. Anemia status of the animals was evaluated every other week using the FAMACHA method to identify the need for individual anthelmintic treatment. Random samples of the NTG herbage available for grazing were taken from each paddock before grazing by using a one-square-meter frame $\left(1 \mathrm{~m}^{2}\right)$. Samples from each bale of NTG hay and each bag of concentrate feed used were also taken for analysis.

At the end of the feeding trial the animals were processed to evaluate carcass characteristics and meat quality. This was done after over- 
night fasting in a commercial slaughterhouse located in Mayagüez, Puerto Rico. Measurements recorded during the slaughter procedure included live weight, warm carcass weight, and hind and fore trunk length. Data were used to calculate dressing, and hind and fore trunk percentages. For further meat quality characterization, the longissimus dorsi muscle of each carcass was dissected and individually frozen in a plastic bag.

Chemical composition analysis was performed in the Animal Nutrition Laboratory of the Department of Animal Science. Samples from each bale of NTG hay and each bag of concentrate feed, hay, and pasture herbage were analyzed for contents of DM, ash, crude protein (CP), neutral detergent fiber (NDF), acid detergent fiber (ADF), and lignin using standard procedures (Van Soest et al., 1991; AOAC, 2000).

Longissimus dorsi muscle samples were analyzed for moisture, fat, and CP content. Moisture was determined by weight loss of $15 \mathrm{~g}$ samples oven dried for $48 \mathrm{~h}$ at $60^{\circ} \mathrm{C}$; fat was determined using an ANK$\mathrm{OM}^{\mathrm{XT10}}$ Extractor ${ }^{5}$ following manufacturing instructions; $\mathrm{CP}$ was determined by the micro-Kjeldahl method as described by AOAC (2000). The $\mathrm{pH}$ was measured in each muscle sample using a $\mathrm{pH}$ meter equipped with a penetrating electrode and a temperature-sensitive $\mathrm{pH}$ adjuster. The muscle color was determined on the fat-free surface with a Minolta colorimeter. All measurements were taken in triplicate for each muscle sample.

A Completely Randomized Design was used, with three observations per treatment within each species. Data were analyzed using the General Linear Model of SAS (SAS Institute, 1994). A t-test for independent samples was performed for mean comparisons of all the independent variables in each treatment within each species. The hypotheses tested were the following: Ho: $\mu_{1}=\mu_{2}$, Ha: $\mu_{1}<\mu_{2}$, using the significance level $\mathrm{P}=0.05$.

\section{RESULTS AND DISCUSSION}

\section{Carcass characteristics of small ruminants slaughtered in Puerto Rico}

The average live weight (LW) of animals in the present study was 28.28 and $29.63 \mathrm{~kg}$ for sheep and goats, respectively (Table 1). Dressing percentage was highly variable in both cases, ranging from 37 to 46 , and 32 to 38 for the two species in the same order. The present

\footnotetext{
${ }^{5}$ Company or trade names in this publication are used only to provide specific information. Mention of a company or trade name does not constitute an endorsement by the Agricultural Experiment Station of the University of Puerto Rico, nor is this mention a statement of preference over other equipment or materials.
} 
TABLE 1.-Carcass yield for sheep and goats raised under extensive conditions in Puerto Rico.

\begin{tabular}{lccc}
\hline & \multicolumn{2}{c}{ Species } & \\
\cline { 2 - 3 } Variable & Sheep $(57)$ & Goat $(28)$ & SEM $^{1}$ \\
\hline Live weight $(\mathrm{kg})$ & 28.28 & 29.63 & 4.67 \\
Warm carcass weight $(\mathrm{kg})$ & 11.50 & 11.01 & 2.35 \\
Dressing \% & $40.11 \mathrm{a}$ & $36.08 \mathrm{~b}$ & 1.27 \\
\hline
\end{tabular}

${ }^{1}$ Standard Error of the Mean

dressing percentage for goats is comparable to the value of $37 \%$ reported for intact male Sidama goats in Ethiopia fed ad libitum grass hay solely (Solomon et al., 2008). However, this dressing percentage is relatively lower than those reported by several authors for indigenous and crossbred goats under similar conditions. A study in Norway showed a dressing percentage of 55 for small east African goats fed with low quality grass hay only (Safari et al., 2009). Other reported values include $43 \%$ for Neuquen Criollo Kids in Argentina (Zimerman et al., 2008), and $43 \%$ also in Maryland, United States, for animals grazing natural grasses (Schoenian, 2009). In a more comparable condition, Liméa et al. (2009) found a dressing percentage of 42 for Creole goats (indigenous Caribbean type) fed only tropical forage in Haiti. For sheep, the average dressing percentage observed in the present study is lower than those reported by Karim et al. (2006) for Kheri lambs in India and Santos et al. (2008) for sheep of a native Portuguese breed grazing natural pastures.

Dressing percentages observed for sheep and goat carcasses under tropical conditions have been very variable and lower than those reported for meat-type animals raised under intensive conditions. One important fact in this regard is that there are different types of crossbreeds, some of which, depending on the genotype, are more suitable as meat-type animals than others. The literature indicates dressing percentages as high as 49 to 55 for ideal meat-type sheep and goats (Shackelford et al., 2006; Burke and Apple, 2007).

The SR included in the present study did not show suitable meattype characteristics. They did not yield a fat carcass, which partially explains the low dressing percentage, since carcass fatness has an important effect on this characteristic (Boggs and Merkel, 1993). Additionally, the late stage of maturity of most of the animals in the present study could result in more compact carcasses and lower dressing percentages (Marichal et al., 2003; Zimerman et al., 2008). Other factors such as the presence of wool and horns in the animals evaluated tend to negatively affect the dressing percentage. Finally, feeding SR 
in tropical regions consists mainly of grazing NTG and shrubs without management of the amount of available forage to meet animal nutritional requirements. This combination of negative factors explains a large part of the typically poor performance of SR for meat in Puerto Rico.

Comparing the two species, there were no differences in average LW and warm carcass weight (WCW) between sheep and goats. However, dressing percentage of sheep was higher $(P<0.05)$ than that of goats (Table 1), which can be attributed to the smaller carcasses and poorer carcass conformation typical of goats at a comparable age (Webb et al., 2005). Other comparative studies of the two species are in agreement with this finding (Santos et al., 2008).

In the present study there were no differences in LW, WCW, and dressing percentage between the sexes of either species (Table 2). These results are in agreement with those of Jiménez-Badillo et al. (2008) and Santos et al. (2008) who found that the sex of the animal did not affect carcass measurements of kid-goats. This finding was attributed to the fact that under tropical conditions, potential effects of the animal's sex on carcass characteristics at the same stage of maturity are not expressed because of the low level of management (Santos et al., 2008). In general, with appropriate management levels, males show more developed carcasses than females in both species (Boggs and Merkel, 1993; Peña et al., 2005).

Effect of supplementation with a commercial concentrate feed on body weight gain, carcass characteristics, and meat quality of weaned lambs and kid-goats

Chemical composition of the feedstuffs used in the present experiment is shown in Table 3. These results indicate that, as expected, the NTG hay and pasture (fresh foliage) if fed alone are inadequate to sup-

TABLE 2-Carcass yields of female and male small ruminants raised under extensive conditions in Puerto Rico.

\begin{tabular}{llcccc}
\hline Species & \multicolumn{1}{c}{ Variable } & Female & Male & SEM $^{3}$ & $P$ \\
\hline Sheep $^{1}$ & Live weight $(\mathrm{kg})$ & 28.19 & 28.49 & 2.62 & 0.934 \\
& Warm carcass weight $(\mathrm{kg})$ & 11.23 & 12.13 & 1.33 & 0.635 \\
& Dressing \% & 39.62 & 41.24 & 1.91 & 0.484 \\
& & & & \\
Goat $^{2}$ & Live weight $(\mathrm{kg})$ & 31.15 & 26.76 & 3.80 & 0.258 \\
& Warm carcass weight $(\mathrm{kg})$ & 11.56 & 9.85 & 1.90 & 0.388 \\
& Dressing \% & 36.30 & 35.74 & 1.68 & 0.402 \\
\hline
\end{tabular}

\footnotetext{
${ }^{1} \mathbf{n}=40$ females, $\mathbf{n}=17$ males

${ }^{2} n=16$ females, $n=11$ males

Standard Error of the Mean
} 
TABLE 3.-Chemical composition of the feedstuffs offered to lambs and kid-goats during the experimental period.

\begin{tabular}{lccc}
\hline Component (\%) & Concentrate & Hay & Pasture \\
\hline Dry Matter & 93.5 & 93.1 & 27.1 \\
Organic Matter $^{1}$ & 95.9 & 93.8 & 93.3 \\
Inorganic Matter $^{1}$ & 4.1 & 6.2 & 6.7 \\
Crude Protein $^{1}$ & $18.2 \mathrm{a}$ & $5.7 \mathrm{~b}$ & $5.8 \mathrm{~b}$ \\
Neutral Detergent Fiber $^{1}$ & $29.2 \mathrm{a}$ & $71.2 \mathrm{~b}$ & $74.3 \mathrm{~b}$ \\
Acid Detergent Fiber $^{1}$ & $11.3 \mathrm{a}$ & $46.9 \mathrm{~b}$ & $49.1 \mathrm{~b}$ \\
Hemicellulose $^{1,2}$ & $17.9 \mathrm{a}$ & $24.3 \mathrm{~b}$ & $25.2 \mathrm{~b}$ \\
Lignin $^{1}$ & - & 6.2 & 6.5 \\
\hline
\end{tabular}

Means in the same row followed by different letter differ significantly $(P<0.05)$

${ }^{1}$ Dry Matter Basis, ${ }^{2}$ Calculated by difference (NDF-ADF)

port optimal SR production, because of their low CP and high fiber contents. Similar values have been reported for other forages harvested in tropical climates (Liméa et al., 2009). An equivalent of 8-12\% CP in the dietary DM is required for normal growth of ruminant animals (Van Soest, 1994).

The nutritional requirements for growing lambs and kid-goats exceed the levels of nutrients that would be supplied by the two forages of the present study, even at high levels of intake. Therefore, supplementation is required to achieve desirable levels of production. In Puerto Rico, the use of CC as supplements for growing SR is a common practice among sheep and goat producers. However, there is limited information on the effectiveness of CC supplementation on lamb and kid-goat performance.

Growth performance of lambs and kid-goats

Daily LW gain for lambs was 33 and $73 \mathrm{~g}$ for non-supplemented and supplemented animals, respectively (Table 4). Supplementation with $\mathrm{CC}$ increased $(\mathrm{p}<0.05)$ total and daily $\mathrm{BW}$ gain in lambs by respective margins of 2,580 and $40 \mathrm{~g}$ when compared to non supplemented animals.

TABLE 4.-Lamb body weight responses to the two treatments.

\begin{tabular}{lccrc}
\hline Variable & Control & Supplemented & SEM $^{1}$ & \multicolumn{1}{c}{$\mathrm{P}$} \\
\hline Initial body weight $(\mathrm{kg})$ & 18.18 & 16.97 & 2.31 & 0.63 \\
Final body weight $(\mathrm{kg})$ & 20.15 & 21.52 & 2.71 & 0.64 \\
Total body weight $\mathrm{gain}(\mathrm{g})$ & $1,966.7 \mathrm{a}^{2}$ & $4,546.7 \mathrm{~b}$ & 606.06 & 0.01 \\
Average daily gain $(\mathrm{g})$ & $33.3 \mathrm{a}$ & $73.3 \mathrm{~b}$ & 9.62 & 0.02 \\
\hline
\end{tabular}

1Standard Error of the Mean

${ }^{2}$ Means in the same row followed by different letter differ significantly $(\mathrm{P}<0.05)$ 
The consistent positive weekly LW change observed in supplemented lambs indicates that the diet provided more nutrients than needed to meet the body maintenance requirements (Figure 1). By contrast, nonsupplemented lambs showed inconsistent weekly LW gains; even though there was an overall increase in LW, weight losses were observed during some weeks of the experimental period. Erratic LW changes in non-supplemented animals may reflect variation in quality of the pasture herbage available for grazing, that together with the grass hay did not meet the minimum $\mathrm{CP}$ ( 8 to $12 \%$ ) and energy (0.96 Mcal $/ \mathrm{kg}$ ) requirements necessary for maintenance (ENm) and LW gain (NRC, 2007).

In this experiment, average rate of daily gain obtained with supplementation was equal to and lower than those reported by Karim et al. (2006) of 73 and $161 \mathrm{~g}$ for lambs raised under extensive and semi intensive management, respectively. There is a marked effect of breed on rate of gain in BW (Schilling, 2005). Low values (50 to $60 \mathrm{~g}$ daily) during growth are common in native breeds of lambs under semi-intensive management, whereas with intensive feeding, such lambs have attained $170 \mathrm{~g}$ (Karim et al., 2006).

Total and daily BW gain in kid-goats was not different $(\mathrm{P}>0.05)$ between treatments (Table 5, Figure 2) despite of supplemented kids showing numerically higher values than the non-supplemented by wide margins. Daily BW gains were 67 and $33 \mathrm{~g}$, respectively. The latter finding agrees with previous work in which daily BW gain in supplemented

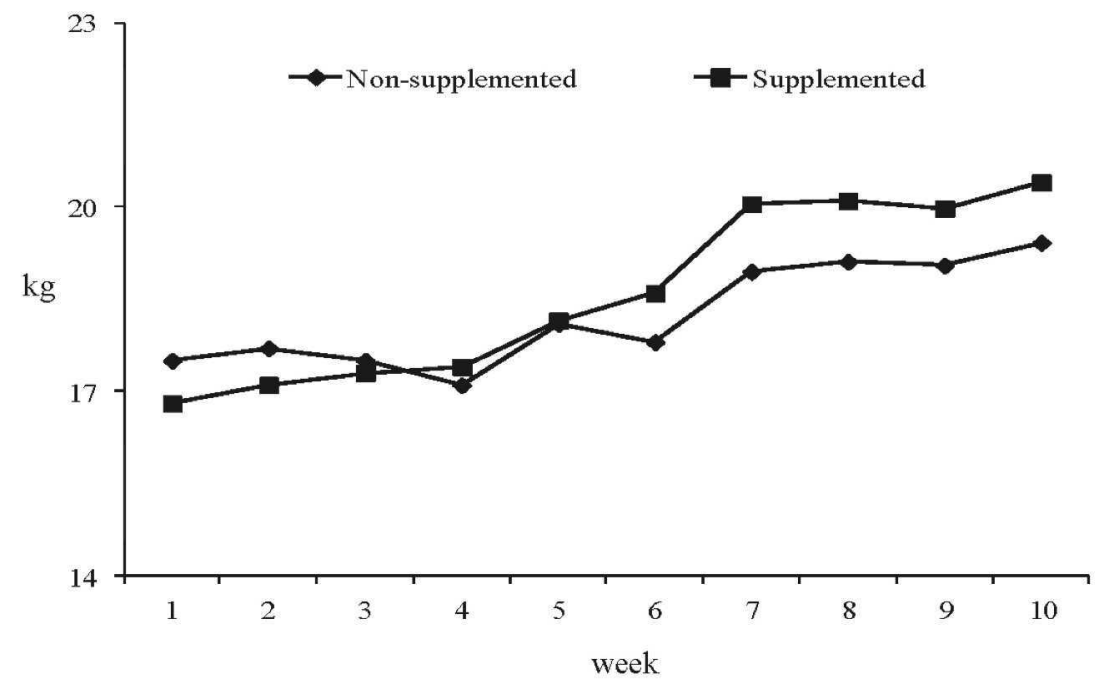

FIGURE 1. Weekly body weight change of lambs during the feeding trial. 
TABLE 5.-Goat body weight responses to the two treatments.

\begin{tabular}{lrcrc}
\hline Variable & Control & Supplemented & SEM $^{1}$ & P \\
\hline Initial body weight $(\mathrm{kg})$ & 15.76 & 16.21 & 2.25 & 0.85 \\
Final body weight $(\mathrm{kg})$ & 17.88 & 20.45 & 2.76 & 0.40 \\
Total body weight gain $(\mathrm{g})$ & $2,123.30$ & $4,243.30$ & $1,329.50$ & 0.19 \\
Average daily gain $(\mathrm{g})$ & 33.30 & 66.70 & 21.11 & 0.21 \\
\hline
\end{tabular}

${ }^{1}$ Standard Error of the Mean

goats did not exceed $65 \mathrm{~g}$ (Solomon et al., 2008). Some authors attribute the low response of goats to supplementation to some inherent characteristics of the species, which consistently lower growth rates below those of other domestic livestock species (Schilling, 2005). Goats tend to have a high propensity to eat selectively, which limits their forage intake under grazing conditions (Rojas et al., 1984; Haenlein, 2001) and a rapid digestive rate (Haenlein, 2001) that may affect nutrient utilization. These characteristics may explain in large measure their lower performance compared to sheep under similar conditions. In addition, goats of most breeds exhibit a significantly smaller mature body size and weight than sheep, which is accompanied by slower growth. This difference could involve the increased frame size of sheep compared to goats (Mc Dowell and Woodward, 1982).

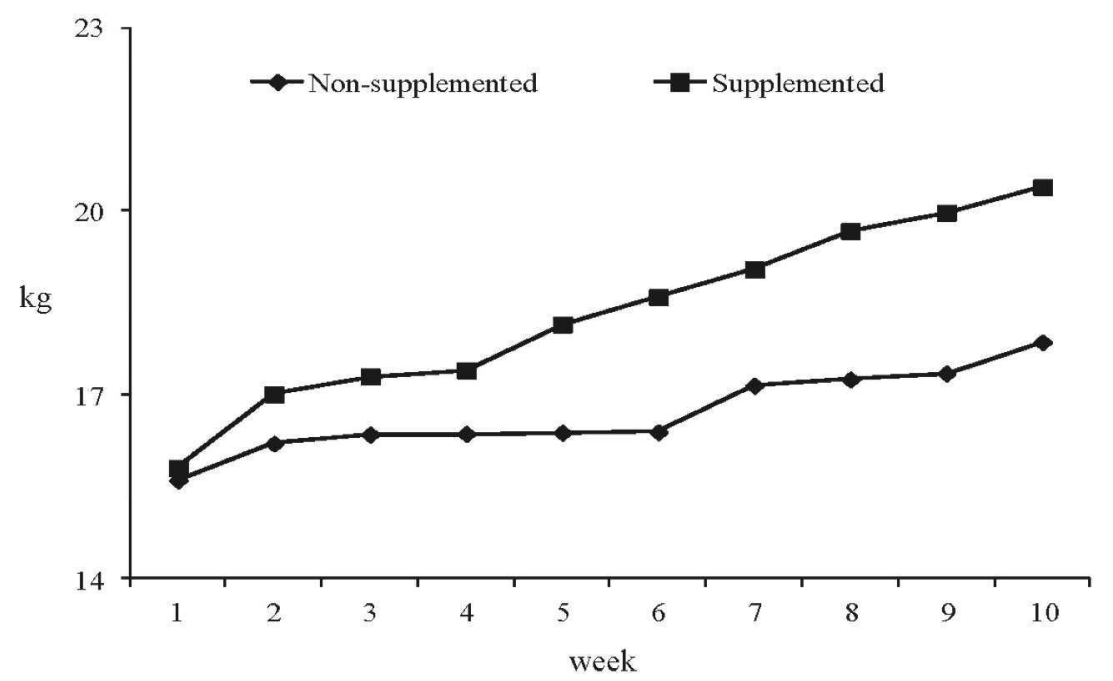

FIGURE 2. Weekly body weight change of kid-goats during the feeding trial. 
In addition to the low quality of NTG there are other factors that might have contributed to the poor animal performance observed in the present study, one of which could be the high mean temperature and other environmental conditions (i.e. precipitation, humidity, solar radiation) under which the study was performed that might be out of the comfort zone of the animals. These factors, along with the low genetic potential could lower feed intake and thus decrease performance.

\section{Carcass characteristics of lambs and kid-goats}

Carcass weight, dressing percentage, and fore and hind trunk percentages in lambs did not vary $(p>0.05)$ with the addition of the concentrate supplement (Table 6). Dressing percentage was 30.86 and 32.35 for control and supplemented lambs, respectively. Certain other authors also found that supplementation with concentrate feed did not significantly affect dressing percentage (Manso et al., 2008; Solomon et al., 2008), whereas in other cases relatively higher dressing percentages have been reported for lamb and kid-goats that grazed native grasses with concentrate supplementation under tropical conditions. Values of $45 \%$ were obtained with Kheri lambs under extensive range management (Karim et al., 2006) and 49\% with Portuguese native breed lambs grazing natural pastures (Santos et al., 2008).

Supplemented animals would normally be expected to show a higher dressing percentage due to improved nutrition. However, research results have been very inconsistent regarding the effects of supplementation with concentrate feed on carcass traits. In agreement with the present study, Manso et al. (2008) found that carcass weight or dressing percentage were not different between Merino lambs fed barley as the sole diet and those supplemented with different protein sources; Solomon et al. (2008) reported no difference in dressing percentages with increasing daily levels ( $200 \mathrm{~g}, 300 \mathrm{~g}$ and $400 \mathrm{~g}$ ) of concentrate feed. Thus, factors other than adequate nutrient supply may have a strong influence on the magnitude of response to supplementation as

TABLE 6.-Effects of commercial concentrate supplementation on lamb carcass characteristics.

\begin{tabular}{lcccc}
\hline Variable & Control & Supplemented & SEM $^{1}$ & P \\
\hline Warm carcass weight $(\mathrm{kg})$ & 6.21 & 6.97 & 0.90 & 0.45 \\
Dressing \% & 30.86 & 32.36 & 1.11 & 0.25 \\
Fore trunk $\%^{2}$ & 46.14 & 45.88 & 2.92 & 0.93 \\
Hind trunk $\%^{2}$ & 53.86 & 54.12 & 2.92 & 0.93 \\
\hline
\end{tabular}

1Standard Error of the Mean

${ }^{2}$ Percentage of the total length that corresponds to this trunk section 
pointed out by Chalupa (1975). In other studies, dressing percentage increased with higher slaughter weight (Manso et al., 2008). Karim et al. (2006) reported higher dressing percentage in Kheri lambs under intensive feeding with ad libitum concentrate supplementation compared to those under extensive grazing.

Similarly, there were no significant differences $(P>0.05)$ in carcass characteristics between supplemented and non-supplemented kidgoats (Table 7). However, dressing percentage, which was 28.11 and 35.59 for control and supplemented animals, respectively, did show a difference of 7.48 percentage units in favor of supplementation. Other authors have reported dressing percentages in the range of 37 to 47 for indigenous and crossbred goats fed with low quality hay and grazing natural grasses (Santos et al., 2008; Liméa et al., 2009; Schoenian, 2009).

Dressing percentage in the present study was similar $(\mathrm{P}>0.05)$ between the two species, in spite of the fact that goats tend to have lower dressing percentages than sheep of comparable age (Webb et al., 2005), as a result of poorer carcass conformation (Santos et al., 2008). However, differences between sheep and goat are minimized under semiarid conditions (Sen et al., 2004). Fore and hind trunk percentages were similar $(\mathrm{P}>0.05)$ for animals within the same species regardless of the treatment. However, the proportion of hind trunk cuts in goats was lower than that in sheep of comparable carcass weight, in agreement with Santos et al. (2008). The dressing percentages of the animals in this experiment were lower than those of the above-mentioned SR harvested in the western region of Puerto Rico. The present study employed animals in an early stage of maturity, which coincides with very poor carcass conformation, whereas those evaluated in the database had already reached their mature carcass conformation.

Chemical composition and quality of the meat

Moisture content was higher and $\mathrm{CP}$ and fat contents were lower, but not significantly $(\mathrm{p}>0.05)$ in the longissimus dorsi muscle of the

TABLE 7.-Effects of commercial concentrate supplementation on hid-goats carcass characteristics.

\begin{tabular}{lcccc}
\hline Variable & Control & Supplemented & SEM $^{1}$ & $\mathrm{P}$ \\
\hline Warm carcass weight $(\mathrm{kg})$ & 5.00 & 6.89 & 1.04 & 0.14 \\
Dressing \% & 28.11 & 35.59 & 2.98 & 0.14 \\
Fore trunk \% & 48.12 & 48.58 & 1.21 & 0.72 \\
Hind trunk \% & 51.88 & 51.42 & 1.21 & 0.72 \\
\hline
\end{tabular}

1Standard Error of the Mean

${ }^{2}$ Percentage of the total length that corresponds to this trunk section 
control animals compared with supplemented animals regardless of species (Table 8). These results agree with other findings of minimal or no differences in carcass composition with the inclusion of supplemental dietary protein (Wilson et al., 1972; Lee et al., 2008). However, there are also reports of increases in these carcass components with increased dietary protein concentration (Kemp et al., 1976). This discrepancy in experimental results may be due to factors such as solubility of the protein, interaction of protein with other nutrients and dietary protein concentration that can negatively affect the utilization of ingested protein (Murphy et al., 1994; Bach et al., 2005). Wilson et al. (1972) noted an increase in longissimus dorsi protein concentration accompanying increased carcass weight. Accordingly, in the present study, the similar slaughter weight of both species resulted in similar carcass composition.

The carcass protein contents found in the present study are similar to those previously reported for lambs and kid-goats (Manso et al., 1998; Werdi et al., 2007; Jabbar and Anjum 2008). The present carcass fat content for lambs and kid-goats are also comparable to some previous findings (Murphy et al., 1994). However, other authors reported higher fat content than those of the present study (Jabbar and Anjum, 2008; Cameron et al., 2001) due to a higher dietary energy density. High-energy diets lead to an increase in ruminal propionate production, which after absorption stimulates fat synthesis. Therefore, reduced carcass fatness in the present study could be associated with several dietary factors including energy source and density. Likewise, the low LW at slaughter may have reduced the differences in carcass component concentrations, since lighter animals are generally leaner. Contrary to the present study, Werdi et al. (2007) reported that supplementation with concentrate feed lowered carcass fat content in grazing goats. The higher fat content obtained with supplementation in the

TABLE 8.-Chemical composition of longissimus dorsi muscle of lambs and kid-goats from the two treatments.

\begin{tabular}{llccc}
\hline Specie & Variable $^{1}(\%)$ & Control & Supplemented & SEM $^{2}$ \\
\hline Lamb & Moisture & 79.58 & 77.18 & 1.65 \\
& Protein & 16.16 & 19.33 & 1.33 \\
& Fat & 4.73 & 5.56 & 0.72 \\
Kid-goat & Moisture & 79.43 & 77.07 & 1.91 \\
& Protein & 17.75 & 19.28 & 1.65 \\
& Fat & 3.07 & 3.90 & 0.90 \\
\hline
\end{tabular}

${ }^{1}$ Dry Matter Basis

2Standard Error of the Mean 
present study may have been caused by the fact that the diet provided less available protein in relation to energy for tissue protein synthesis, resulting in more energy being deposited as fat (Manso et al., 1998). This difference could also be partially due to breed type. It has been suggested that animals with lower growth rate potential, such as those used in the present study, have a higher percentage of intramuscular fat than fast-growing animals (Murphy et al., 1994).

Carcass moisture and protein contents were not different $(\mathrm{P}>0.05)$ between species; however, fat content was numerically lower for kidgoats (Table 8). This difference is due to the fact that goats tend to store a great proportion of their body fat internally, rather than subcutaneously or intramuscularly, thus producing carcasses which are leaner than those of sheep of similar ages (El Khidir et al., 1998). Likewise, fat development in goats occurs very late in maturity (Dhanda et al., 1999).

No significant differences were found in the $\mathrm{pH}$ values of longissimus dorsi muscle between supplemented animals and those fed forage solely; however, the latter showed a higher value (Table 9). High $\mathrm{pH}$ levels in SRM are consistent with the findings of several authors (Werdi et al., 2007; Safari et al., 2009). The high $\mathrm{pH}$ found in meat from sheep and goats has been ascribed to their high susceptibility to stress (Webb et al., 2005), which results in a depletion of muscle glycogen (Dhanda et al., 1999). Similar to the present results, previous studies suggest that meat from forage-fed animals has higher $\mathrm{pH}$ values than that of grain-fed animals (Muchenje, et al., 2009), since the former have lower glycogen reserves due to nutritional insufficiencies (Safari et al., 2009). Therefore, the high $\mathrm{pH}$ values in the present study could be partially attributed to the low plane of nutrition that

TABLE 9.- $p H$ and color parameters of longissimus dorsi muscle of lamb and kid-goat carcasses from the two treatments.

\begin{tabular}{lccccc}
\hline Specie & Variable & Control & Supplemented & SEM $^{1}$ & $\mathrm{P}$ \\
\hline Lamb & $\mathrm{pH}$ & 6.02 & 5.66 & 0.35 & 0.367 \\
& $\mathrm{~L}^{*}$ & $41.70 \mathrm{a}^{2}$ & $50.42 \mathrm{~b}$ & 1.42 & 0.002 \\
& $\mathrm{a}^{*}$ & 11.08 & 10.85 & 0.48 & 0.661 \\
& $\mathrm{~b}^{*}$ & 10.85 & 9.93 & 0.46 & 0.114 \\
Kid-goat & & & & & \\
& $\mathrm{pH}$ & 5.94 & 5.59 & 0.25 & 0.233 \\
& $\mathrm{~L}^{*}$ & 33.95 & 38.18 & 1.00 & 0.013 \\
& $\mathrm{a}^{*}$ & 16.18 & 14.66 & 0.66 & 0.083 \\
& $\mathrm{~b}^{*}$ & 9.66 & 10.31 & 0.40 & 0.182 \\
\hline
\end{tabular}

1Standard Error of the Mean

${ }^{2}$ Means in the same row followed by different letter differ significantly $(P<0.05)$. 
the animals were on. A high muscle $\mathrm{pH}$ (above 5.8) occurs as a result of depleted levels of glycogen, and is generally associated with darker meat color (Lawrie, 1991). The muscle glycogen is used up rapidly during the handling, transport, and pre-slaughter period, leaving little lactic acid production after slaughter, which results in Dark-Firm-Dry (DFD) meat. However, $\mathrm{pH}$ variations must be of a certain magnitude in order to affect the quality of the meat (Safari et al., 2009). Therefore, hydrogen ion concentration in the present study was not low enough to produce DFD. This conclusion was supported by the high $\mathrm{L}^{*}$ value found (Table 9).

The dietary treatment had a significant $(\mathrm{P}<0.05)$ influence on the longissimus dorsi muscle $\mathrm{L}^{*}$ value of lamb meat, but not on the $\mathrm{a}^{*}$ and $\mathrm{b}^{*}$ values. The said muscle color was lighter (higher $\mathrm{L}^{*}$ value) in the supplemented animals than in those fed only grass. The darker color (low $\mathrm{L}^{*}$ values) in non-supplemented animals may be attributed to a decreased muscle glycogen as noted. These results are in agreement with those of other authors who reported that meat from forage-fed animals is darker colored than that of those fed grain (Priolo et al., 2002; Lee et al., 2008; Muir et al., 1998) due to the higher $\mathrm{pH}$ values found in the former. However, other authors did not find such differences in meat $\mathrm{pH}$ between forage-fed and grain-fed animals or found lighter color in meat from concentrate-fed steers (French et al., 2000; Razminowicz et al., 2006; Lee et al., 2008). No differences in $b^{*}$ coordinates were found between the supplemented and non-supplemented treatments in the present study, probably because marked differences due to different dietary combinations of forage-concentrate do not develop over a short period of time (French et al., 2000). Likewise, differences in meat quality caused by dietary effects are diminished when animals are harvested at light weight. Other authors reported that the meat of animals fed on pasture solely have more yellowness (higher $\mathrm{b}^{*}$ value) from ingesting the high levels of beta-carotene contained in the grass (Muchenje et al., 2009).

When comparing meat from lambs and kids, the latter showed lower lightness and higher redness because of the lower intramuscular fat content of their carcasses. However, consumers cannot readily perceive the differences in meat color between these two species (Lee et al., 2008). Results from these studies show that factors such as poor pasture quality and low genetic potential of the animals might negatively affect performance under CC supplementation. Selection for improved genotypes as well as research on alternative, less expensive feed sources for finishing meat-type animals, would contribute to improving quantity and quality of local SRM. 


\section{CONCLUSIONS}

Small ruminants slaughtered commercially in Puerto Rico were shown to have highly variable dressing percentages (observed values ranged from 37 to 46 for sheep, and 32 to 38 for goats), the mean values favoring sheep (39.6 vs. 36.3 in females, and 41.2 vs. 35.7 in males). Over all, the animal's sex had little effect on this variable. Supplementation with $\mathrm{CC}$ increased the rate of $\mathrm{BW}$ gain significantly $(\mathrm{P}<$ $0.05)$ in lambs and appreciably but not significantly $(P>0.05)$ in kidgoats above non-supplemented controls. Dressing percentage, and fore and hind trunk percentages of the carcass did not vary between treatments for either species. Lower $\mathrm{pH}$ and moisture content and higher $\mathrm{CP}$ and fat percentages of longissimus muscle were trends observed in supplemented animals relative to control. However, supplementation was more effective in increasing the rate of gain of the animals than in improving the characteristics of the carcass or the meat composition during the relatively short duration of this study.

\section{LITERATURE CITED}

AOAC, 2000. Official Methods of Analysis $13^{\text {th }}$ edition. Association of Official Analytical Chemists. Washington, D.C.

Bach, A., S. Calsamiglia and M. Stern, 2005. Nitrogen metabolism in the rumen. J. Dairy Sci. 88: (E. Suppl.) E9-E21.

Boggs, D. and R. Merkel, 1993. Live Animal Carcass Evaluation and Selection Manual. $4^{\text {th }}$ ed. Kendall/Hunt Publishing Company. Dubuque, IA.

Burke, J. and J. Apple, 2007. Growth performance and carcass traits of forage-fed hair sheep. Small Rum. Res. 67:264-270.

Cameron, M., T. Sahlu, J. Luo, S. Hart, S. Coleman and A. Goetsch, 2001. Growth and slaughter traits of Boer x Spanish, Boer x Angora, and Spanish goats consuming a concentrate based diet. J. Anim. Sci. 79:1423-1430.

Chalupa, W., 1975. Rumen by-pass and protection of proteins and amino acids. J. Dairy. Sci. 68: 1198-1206.

Department of Agriculture of Puerto Rico, 2008. Office of Agricultural Statistics. San Juan, PR.

Dhanda, J., D. Taylor, P. Murray and J. McCosker, 1999. The influence of goat genotype on the production of Capretto and Chevon carcasses. Growth and carcass characteristics. Meat Sci. 52: 355-361.

El Khidir, I., S. Babiker and S. Shafie, 1998. Comparative feedlot performance and carcass characteristics of Sudanese desert sheep and goats. Small Rum. Res. 30:147151.

Foreign Trade Statistics, 2004. U.S. Trade with Puerto Rico and U.S. possessions. United States Department of Commerce. Washington, DC.

French, P., E. O'Riordan, F. Monahan, P. CaVrey, M. Vidal and M. Mooney, 2000. Meat quality of steers finished on autumn grass, grass silage or concentrate based diets. Meat Sci. 56: 173-180.

Haenlein, G., 2001. Past, present, and future perspectives of small ruminant dairy research. J. Dairy Sci. 84:2097-2115. 
Jabbar, M. and M. Anjum, 2008. Effect of diets with different forage to concentrate ratio for fattening of Lohi lambs. Pak. Vet. J. 28(3):150-152.

Jiménez-Badillo, M., S. Rodrígues, E. Pereira, C. Sanudo and A. Costa, 2008. Effect of sex and carcass weight $(4,6,8 \mathrm{~kg})$ on carcass and meat quality of "Cabrito Transmontano" (PDO). Proc. of the $9^{\text {th }}$ Int. Goat Conf. Querétaro, Mexico. pp. 82.

Karim, S., K. Porwal, S. Kumar and V. Singh, 2006. Carcass traits of Kheri lambs maintained on different system of feeding management. Meat Sci. 76:395-401.

Kemp, J., A. Johnson, D. Steward, D. Ely and J. Fox, 1976. Effect of dietary protein, slaughter weight and sex on carcass composition, organoleptic properties, and cooking losses of lamb. J. Anim. Sci. 42:575-583.

Lawrie, R., 1991. Meat Science. $5^{\text {th }}$ ed. Pergamon Press. New York.

Lee, J., B. Kouakou and G. Kannan, 2008. Chemical composition and quality characteristics of chevon from goats fed three different post-weaning diets. Small Rum. Res. 75:177-184.

Liméa, L., M. Boval, N. Mandonnet, G. García, H. Archimède and G. Alexandre, 2009. Growth performance, carcass quality, and noncarcass components of indigenous Caribbean goats under varying nutritional densities. J. Anim. Sci. 87:3770-3781.

Manso, T., A. Mantecon, F. Giraldez, P. Lavin and T. Castro, 2008. Animal performance and chemical body composition of lambs fed diets with different protein supplements. Small Rum. Res. 29:185-191.

Marichal, A., N. Castro, J. Capote, M. Zamorano and A. Argüello, 2003. Effects of live weight at slaughter (6,10 and $25 \mathrm{~kg})$ on kids carcass and meat quality. Livest. Prod. Sci. 83: 247-256.

McDowell, R. and A. Woodward. 1982. Concepts in animal adaptation. Comparative suitability of goats, sheep, and cattle in tropical environments. Proc. 3rd. Int. Goat Conf., Tucson, AZ. pp 387.

Muchenje, V., K. Dzama, M. Chimonyo, P. Strydom, A. Hugo and J. Raats. 2009. Some biochemical aspects pertaining to beef eating quality and consumer health: A review. Food Chem. 112:279-289.

Muir, P., J. Beaker and M. Brown, 1998. Effects of forage- and grain-based feeding systems on beef quality: A review. NZJ. Agri Res. 41:623-635.

Murphy, T., S. Loerch, K. McClure and M. Solomon, 1994. Effect of grain or pasture finishing system on carcass composition and tissue accretion rates of lambs. J. Anim. Sci. 72: 3138-3144.

NRC, 2007. Nutrient Requirements of Small Ruminants: Sheep, Goats, Cervids, and New World Camelids. The National Academic Press, Washignton, D.C.

Peña, F., T. Cano, V. Domenech, J. Alcalde, J. Martos, A. García-Martínez, M. Herrera and E. Rodero, 2005. Influence of sex, slaughter weight and carcass weight on "noncarcass" and carcass quality in segureña lambs. Small Rum. Res. 60:247-254

Priolo, A., D. Micol and J. Agabriel, 2002. Effects of grass feeding systems on ruminant meat colour and flavour: A review. Anim. Res. 50:185-200.

Razminowicz, R., M. Kreuzer and M. Scheeder, 2006. Quality of retail beef from two grass-based production systems in comparison with conventional beef. Meat Sci. 73:351-361.

Rojas, J., M. de Chávez and R. Fernández, 1984. Capacidad comparativa de digestión entre ovinos y caprinos. Zootec. Trop. 2:20-29.

Safari, J., D. Mushi, L. Mtenga, G. Kifaro and L. Eik, 2009. Effects of concentrate supplementation on carcass and meat quality attributes of feedlot finished Small East African goats. Lives. Sci. 125:266-274

Santos, V., S. Silva and J. Azevedo, 2008. Carcass composition and meat quality of equally mature kids and lambs. J. Anim. Sci. 86:1943-1950. 
SAS Institute,1994. User's guide, version. SAS Inst., Cary, N.C.

Schilling, B., 2005. Performance evaluation, carcass characterization, and palatability assessment of hair sheep. M.S. Thesis. Texas Tech University. Department of Animal Science. Lubbock, TX.

Schoenian, S., 2009. Meat goat carcass evaluation. Western Maryland asture-based meat goat performance test. Maryland Cooperative Extension. University of Maryland.

Sen, A., A. Santra and A. Karim, 2004. Carcass yield, composition and meat quality attributes of sheep and goat under semiarid conditions. Meat Sci. 66: 757-763.

Shackelford, S., K. Leymaster, T. Wheeler and M. Koohmaraie, 2006. Lamb Meat Quality Progress Report Number 1. Preliminary Results of an Evaluation of Effects of Breed of Sire on Carcass Composition and Sensory Traits of Lamb. USDA, ARS, Meat Animal Research Center. Clay Center, NE.

Solomon, M., S. Melaku and A. Tolera, 2008. Supplementation of cottonseed meal on feed intake, digestibility, live weight and carcass parameters of Sidama goats. Lives. Sci. 119:137-144

Van Soest, P.J., J. B. Robertson and B. A. Lewis, 1991. Methods for dietary fiber, neutral detergent fiber, and nonstarch polysaccharides in relation to animal nutrition. $J$. Dairy Sci. 74:3583-3597.

Van Soest, P. J., 1994. Nutritional Ecology of the Ruminant, $2^{\text {nd }}$ ed. Cornell University Press. Ithaca, NY. pp. 176.

Webb, E., N. Casey and L. Simela, 2005. Goat meat quality. Small Rum Res. 60:153-166.

Werdi, N., P. Murray and D. Taylor, 2007. Feral goats in Australia: A study on the quality and nutritive value of their meat. Meat Sci. 75: 168- 177.

Wilson, L., M. Borger, A. Peterson, M. Rugh and C. Orley, 1972. Effects of zeranol, dietary protein level and methionine hydroxy analog on growth and carcass characters and certain blood metabolites in lambs. J. Anim. Sci. 35:128-132.

Zimerman, M., E. Domingo and M. Lanari, 2008. Carcass characteristics of Neuquen Criollo kids in Patagonia Region, Argentina. Meat Sci. 79: 453-457. 